\title{
Konsekvenser av dagliga gratistidningar på marknaden - svenska erfarenheter
}

\author{
Af Ingela Wadbring
}

I denne artikel beskriver forfatteren de seneste mere end 10 års erfaringer med gratisaviser $i$ Sverige. Det var $i$ Sverige, at den forste udgave af, trafikavisen' Metro (metroXpress $i$ Danmark) udkom forste gang. Det er derfor $i$ Sverige man i langst tid har kunnet observere den nye medietypes indvirkning på de etablerede dagblade - og på medieudviklingen $i$ det hele taget. Forfatteren beskriver både de kommercielle og adfardsmassige konsekvenser af Metros og konkurrerende gratisavisers indtog på det svenske marked; fra truslen mod de etablerede avisers indtjeningsmuligheder til de nye lasere som gratisaviserne har rekrutteret til dagbladsmediet. Artiklen er skrevet for den såkaldte aviskrig brod du i Danmark $i$ efteråret 2006, udlost af den den islandske koncern Baugurs proklamering om et nyt landsdakkende, husstandsomdelt dagblad - Nyhedsavisen - hvis mål var på kort tid at få en million lasere $i$ Danmark. Artiklen forholder sig ikke til den konkrete situation i Danmark, men rummer refleksioner over det grundlag man kan vurdere dagbladenes situation og udviklingsmuligheder på $i$ et marked, der er pt er inde $i$ en dramatisk periode.

När världens första moderna dagliga gratistidning, Metro, startade i Stockholm 1995 var det vid den tidpunkt då alla talade om sjunkande upplagor för dagspressen, tidningens snara död och internet som världens frälsare. Det var allt annat än opportunt att starta en ny papperstidning då. Ändå skedde det, och framgången lät inte vänta på sig. Sedan grunden för Metro lagts i Stockholm 1995 har ungefär 70 systertidningar startat inom samma företag världen över (Bakker \& Wadbring 2005, se också www.metro.lu), och många andra företag har också tagit upp kampen genom att starta egna dagliga gratisdistribuerade tidningar (Bakker 2002b, Ifra 2005, Price 2002). Det numera Londonbaserade företaget Metro International har en klart expansionistisk strategi, medan många andra företag antingen startar en daglig gratistidning för att mota en eventuell Metrolansering eller för att få del av den stora annonsmarknad som visat sig finnas för denna typ av tidningar (Picard 2001, jfr Bakker 2002a).

Att många mediehus världen över också har i princip färdiga dummys liggande för en egen daglig gratisdistribuerad tidning är klart. Rädslan är stor att en Metro, en 20 Minuter eller en Urban ska dyka upp på marknaden; skulle så ske måste man vara beredd. Det sås man inte minst under 2006 i Danmark där den isländska koncernen Baugur samtidigt som de danska medie företagen Berlingske och JP/Politikken startade dagliga hemdistribuerade gratistidningar (se Dansk Presse, löpande).

Men vilka konsekvenserna egentligen blir på marknader där det startar dagliga gratistidningar vet man inte så mycket om. Denna artikel ska ge åtminstone ett delsvar på en sådan fråga, även om den isländska och danska satsningen ännu inte kan tas med i analysen. Eftersom den dagliga gratistidning i världen som funnits allra längst är Metro i Stockholm - och i Göteborg några år senare - kan svaret ges för just denna geografiska marknad: vilka är konsekvenserna av Metros start på tidningsmarknaden i Sverige? ${ }^{1}$ Hösten 2002 startade den dominerande mediekoncernen i Stockholm, Bonniers, en konkurrerande daglig gratistidning i Stockholm: Stockholm City. I den mån det är möjligt tas hänsyn också till denna i analysen. ${ }^{2}$ 


\section{Två perspektiv}

När konsekvenserna av en ny tidnings start ska studeras, kan flera olika perspektiv anläggas. När en ny tidning startar på en befintlig marknad, innebär det att den blir andra- eller till och med tredjetidning på marknaden (Gustafsson 1996, Høst 1996, Picard 1993). Många etableringshinder ska forceras på vägen för den nyetablerade tidningen, men det innebär också att befintliga tidningar utmanas och att konkurrensen därmed totalt sett ökar.

Konkurrensen och marknadsutvecklingen är möjlig att studera med hjälp av offentligt material. Från ett ekonomiskt perspektiv är båda marknaderna som en tidning verkar på, dvs. annons- och upplagemarknaderna, relevanta att studera. En traditionell svensk morgontidning får merparten av sina intäkter från annonsmarknaden (cirka 60 procent, storstadstidningarna något mer än landsortstidningarna), medan kvällstidningarna får merparten av sina intäkter via läsarnas lösnummerköp, cirka 75 procent (Tidningsutgivarna 2005). En gratisdistribuerad tidning får samtliga intäkter från annonsörerna, men konkurrerar ändå med andra tidningar om läsarna eftersom dessa förväntas investera åtminstone tid och intresse, om än inte pengar, i tidningen. Naturliga mått för att studera konsekvenserna av en ökad konkurrens ur ett ekonomiskt perspektiv är genom upplagor och upplageintäkter respektive annonsintäkter. ${ }^{3}$

Eftersom medier i allmänhet, och public service liksom morgontidningar i synnerhet, dessutom menar sig ha ett samhällsuppdrag (McAllister 1996, Nord \& Strömbäck 2004), är det av relevans att också anlägga ett samhälls- eller demokratiperspektiv när konsekvenserna av en ny tidningsstart analyseras. Tidningar har av tradition haft publicistiska och opinionsbildande ambitioner, även om de över tid kommit att allt mer att fungera som vilka företag som helst (Baldasty 1992, Hultén 1999, McManus 1994). ${ }^{4}$ För att det ska vara poängfyllt att anlägga ett samhälls- eller demokratiperspektiv måste utgångspunkten vara att mediernas innehåll är tillräckligt relevant för att kunna fylla en funktion för att orientera sig i samhället. Min utgångspunkt här är att samtliga tidningar har ett sådant innehåll, såväl morgon-, som kvälls- och dagliga gratisdistribuerade tidningar, om än i olika grad och av olika slag (Wadbring 2003, jfr Høst 2000).
Om tidningarna ses som viktiga från ett samhällsperspektiv, blir andra mått än upplagor och annonsintäkter relevanta: primärt användnings- eller räckviddsmått liksom värderingsmått (för översikter, se McQuail 2005, Sternvik, Weibull \& Nilsson 2005). I denna artikel har endast räckvidds- och användningsmått använts för att studera hur läsningen av tidningarna förändrats som en konsekvens av de dagliga gratistidningarnas start.

\section{Tidningsmarknaden i Sverige och Stockholm omkring 1995}

De svenska morgontidningarna är samtliga lokala i bemärkelsen att de sprids lokalt. Storstadsmorgontidningarna har förvisso en bevakning som är mer än lokal, men inte ens den största morgontidningen, Dagens Nyheter, har en spridning på mer än cirka 5 procent bland boende utanför Stockholm trots att en stor andel av upplagan ligger utanför Stockholmsregionen (TS-boken, löpande). De fyra kvällstidningarna utkommer numera likt morgontidningarna på morgonen, men de är lösnummerförsålda och har en annan slags nyhetsbevakning som lutar mer åt underhållning. ${ }^{5}$ De två kvällstidningar som utkommer i Stockholm är båda nationella till sin karaktär, medan de båda övriga är regionala i Göteborgs- respektive Malmöregionen.

Sverige är ett av de mer tidningstäta länderna i världen. Enligt WAN (2005) är Sverige den tredje mest tidningsläsande nationen i världen, efter Japan och Norge, sett till förhållandet mellan upplaga och antal vuxna invånare. Men det finns relativt stora skillnader mellan olika regioner i landet. Stockholmsregionen har under lång tid utmärkt sig gentemot resten av landet genom att morgontidningarnas ställning inte är så stark; detta trots att Stockholmsregionen är en av relativt få regioner i Sverige där det länge funnits två dagliga morgontidningar och två dagliga kvällstidningar.

När Metro startade i Stockholm i mitten av februari 1995 fick regionen en tredje daglig morgontidning, en gratisdistribuerad sådan. Bruttoupplagan i regionen gick därmed upp med ungefär 200.000 exemplar (figur 1). När den andra dagliga gratisdistribuerade morgontidningen, Stockholm City, startade 2002 ökade bruttoupplagan i regionen ytterligare en gång med cirka 200.000 exemplar. ${ }^{6}$ 


\section{Figur 1}

Tidningsupplagor i Stockholmsregionen 1990-2005 (tusentals exemplar)

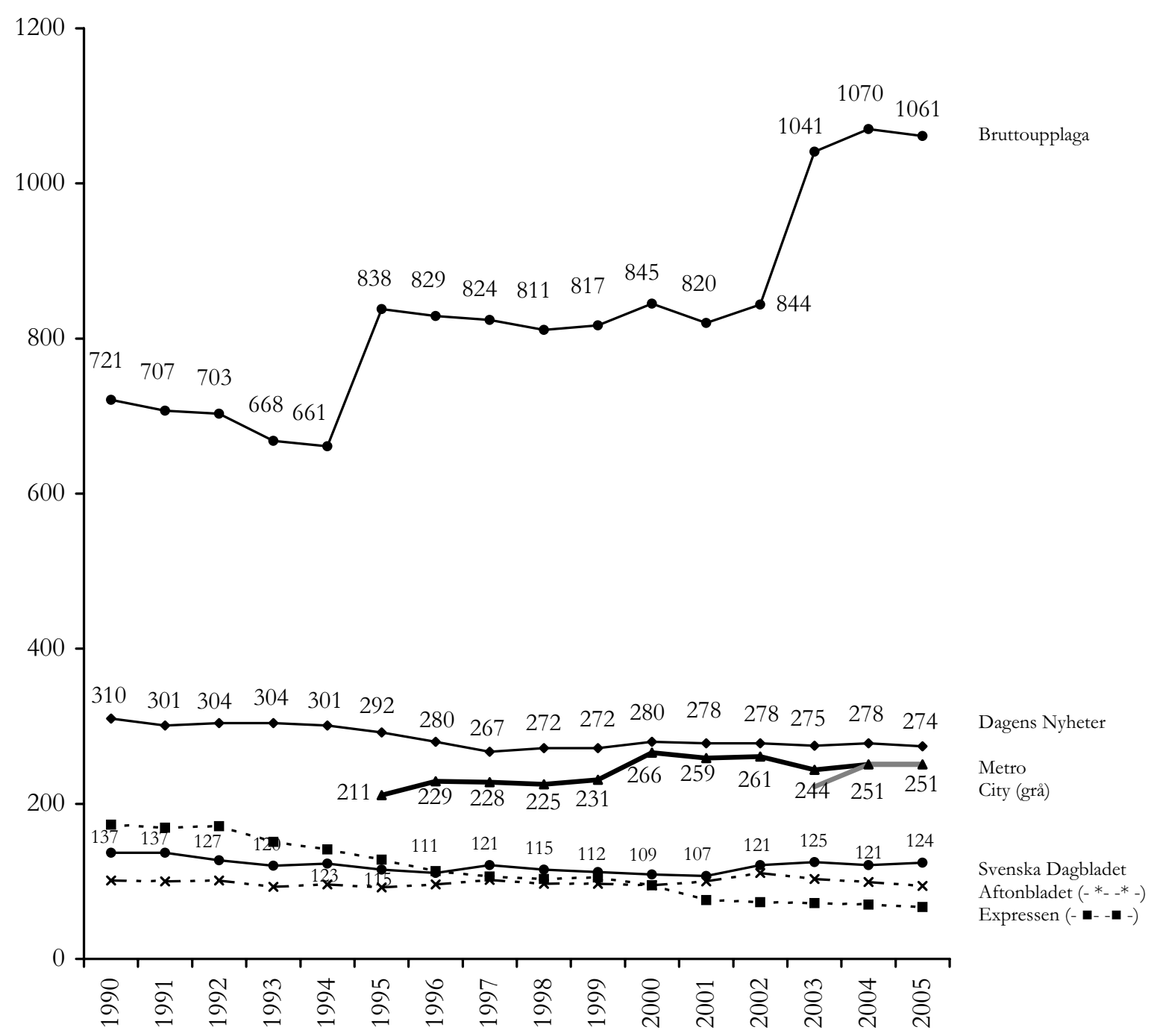

Kommentar: TS mätte till och med år 1994 upplagor för första halvåret respektive år, och från och med 1995 helårsvis. Metro och Stockholm City är mätta enligt RS, inte TS (se www.ts.se). Siffror är endast utsatta på Dagens Nyheter, Metro och Svenska Dagbladet. De två senaste åren visar Metro och City exakt samma siffror. Bruttoupplaga innebär sammanlagd upplaga av samtliga i figuren ingående titlar.

Källa: TS och RS respektive år.

Vad som är slående när upplagorna för tidningarna i Stockholmsregionen studeras, är att det är en mycket måttlig nedgång för de abonnerade tidningarna på marknaden trots starten av två dagliga gratisdistribuerade tidningar med stora upplagor. Den nedgång som kan ses, framför allt för Dagens Nyheter, började långt dessutom innan Metro startade. Kvällstidningarna synes helt opåverkade; Expressens upplaga befann sig i Stockholmsregionen i fritt fall under hela 1990talet och Aftonbladets upplaga var relativt stabil under 1990-talet. ${ }^{7}$ 
Samtidigt kan konstateras att en viss upplagenedgång finns för de båda abonnerade morgontidningarna, även om den är mindre än vad som kunnat väntas med tanke på hur stor Metros, och sedan Citys, upplaga var redan inledningsvis. Dagens Nyheters upplaga faller några år efter Metros start, men därefter kan en återhämtning ses. När den dagliga gratisdistribuerade Stockholm City startade 2002 synes det påverka övriga tidningars upplagor endast måttligt.

I Göteborg där det finns en lokal morgontidning och en lokal kvällstidning är mönstret lite annorlunda. När Metro startade där 1998 gjorde den det med drygt 70.000 exemplar; den är alltså betydligt mindre där än i Stockholmsregionen. GöteborgsPosten minskade i upplaga under 1980- och 1990talen precis som Dagens Nyheter, men mycket måttligt, och ingen särskilt nedgång kan direkt tillskrivas tidpunkten för Metros start. Nedgången ligger i huvudsak under första halvan av 1990-talet, alltså innan Metro startat. GT har haft en stor upplagenedgång under 1990-talet, men också den huvudsakligen före 1998 då Metro startade (för dataredovisning, se Wadbring 2003).

Sammantaget kan konstateras att upplagenedgångar finns i såväl Stockholm- som Göteborgsregionerna under 1990-talet, men det är inte helt självklart att dessa nedgångar kan knytas till starten av Metro; vi vet inte hur det hade sett ut om denna tidning inte startat (jfr Mahoney \& Collins 2005). Det finns också andra förklaringar som är plausibla, till exempel att internet började växa ungefär samtidigt som Metro startade (se Bergström 2004) eller att det är en allmän trend för samtliga storstadsmorgontidningar med sjunkande upplagor under 1990-talet som hade fortsatt även utan Metros inträde på marknaden.

Man får heller inte glömma de förändringar som skett utanför tidnings- eller mediemarknaden under 1990-talet och som kan vara viktiga förklaringar avseende upplagenedgångar och nedgång i tidningsläsning. Exempel på sociala samhällsförändringar av betydelse är en förändrad hushållssammansättning genom en större andel ensamhushåll (och alldeles särskilt i Stockholmsregionen), en betydligt större andel unga som läser på universitet/högskola (närmast en fördubbling under 1990-talet), en ökad medelålder hos mödrar vid första barnets födelse etc. Det är många faktorer som sammantaget innebär att man är ung, eller lever ett ungt liv, längre upp i åldrarna än någonsin förut och det är också faktorer som inte verkar i gynnsam riktning för det stabila liv som är nära sammanlänkat med hushållsprenumeration och regelbunden läsning av lokala morgontidningar (Wadbring \& Weibull 2005a).

Men även om vi således aldrig kan vara säkra på att det är just Metro som orsakat den nedgång som kan ses, kan vi komma ett steg vidare i analysen av eventuella konsekvenser på tidningsmarknaden. Ett sätt är att se i vilken utsträckning tidningsföretagen kunnat ta betalt för sin redovisade upplaga. I figur 2 finns såväl Dagens Nyheter och Svenska Dagbladet som Göteborgs-Posten redovisade. Staplarna visar tidningens totala upplaga i regionen och kurvan som löper över staplarna visar den del av upplagan som kan sägas vara fullbetald, dvs. här definierat som att den har maximalt 25 procents rabatt.

Förändringen av den procentuella betalningsgraden, som redovisas överst för respektive tidning, bevisar förvisso inte heller att starten av Metro har bidragit till andra morgontidningars upplagenedgång, men stödjer ändå hypotesen om att så mycket väl kan vara fallet. Med början i Stockholm kan vi se att betalningsgraden går ned för såväl Dagens Nyheter som Svenska Dagbladet med start i mitten av 1990-talet. Mest märkbart är det för Svenska Dagbladet, vilket också är logiskt med tanke på att den var klar andratidning på marknaden när Metro startade. Under 2000-talets första år har Svenska Dagbladet ökat sin totala upplaga radikalt, men inte lyckats öka betalningsgraden i motsvarande mån.

Huruvida Svenska Dagbladets ökning av den totala upplagan 2002 har direkt koppling till starten av Stockholms City går inte att veta, men det känns inte orimligt att anta att Svenska Dagbladet vill kunna visa en relativt stor upplaga för annonsörerna; låt vara att man inte har lyckats ta betalt för den av läsarna. Sedan 2002 när Stockholm City startade går betalningsgraden ned också för Dagens Nyheter, och även här kan man naturligtvis ana ett samband. I regionen finns två dagliga gratisdistribuerade tidningar med en gemensam upplaga på nästan 500.000, och på ett sätt är det 
Figur 2

Total upplaga i förhållande till betald upplaga för morgontidningarna i Stockholms- och Göteborgsregionen, 1990-2005 (tusentals exemplar)

a) Dagens Nyheter i Stockholmsregionen

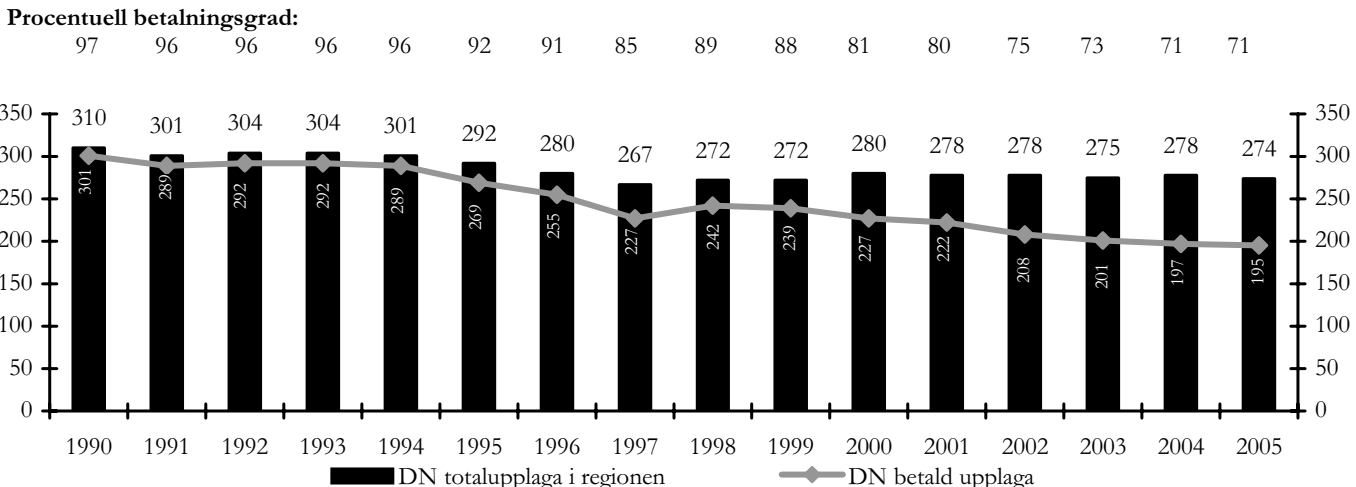

b) Svenska Dagbladet i Stockholmsregionen

Procentuell betalningsgrad:

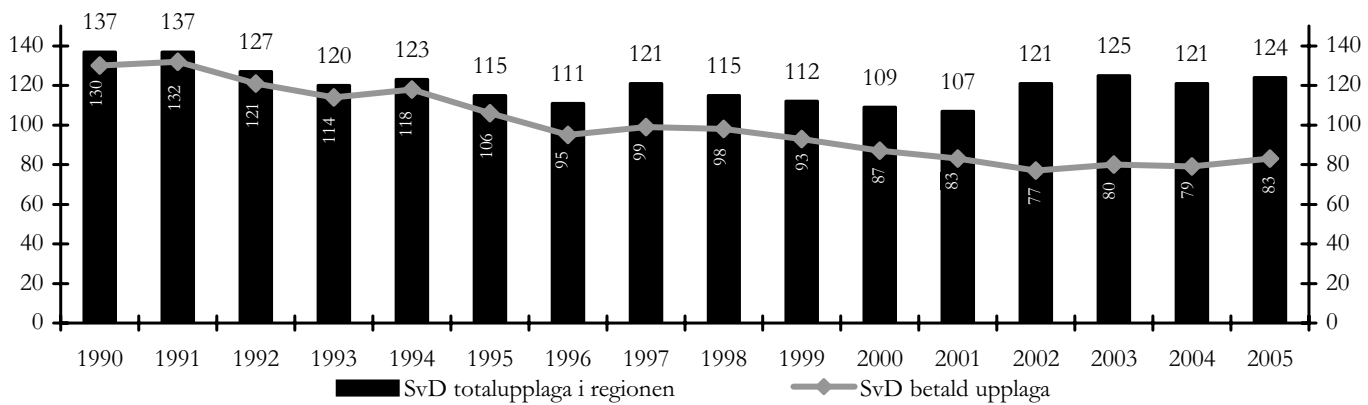

c) Göteborgs-Posten i Göteborgsregionen

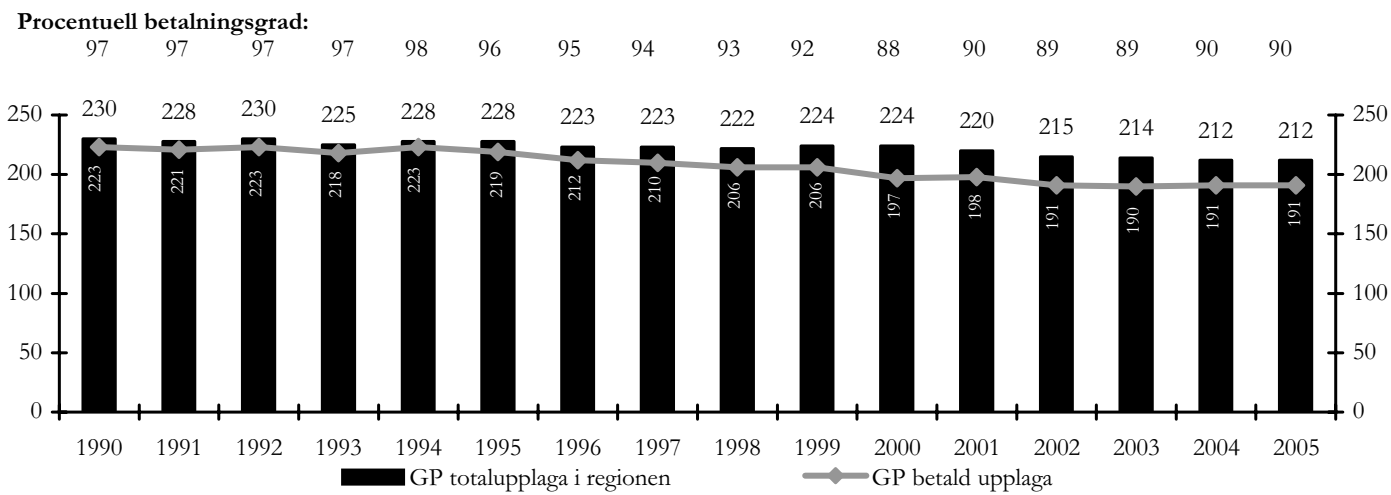

Källa: TS-boken respektive år (bearbetning).

Kommentar: Staplarna visar den totala upplagan i respektive region, och kurvan visar en uppskattning av hur stor andel av denna upplaga som är fullbetald med maximalt 25 procents rabatt eller är lösnummerförsåld. För detaljer om hur beräkningen är gjord, se Wadbring (2003:239ff). 
därför fascinerande att de abonnerade morgontidningarna inte tappar än mer än vad de gör. Dessutom pågår naturligtvis ständigt ett »krig« mellan de båda abonnerade tidningarna där vapnet är rabatter av olika slag. Att detta krig intensifierats efter starten av fler tidningar i regionen är rimligt att tänka sig. Den allmänna konkurrensen ökar.

Betalningsgraden för Göteborgs-Posten i Göteborg går också ned något över tid, men kommer ändå i princip aldrig under 90 procent. Jämför man med andra abonnerade morgontidningar i Sverige så ligger betalningsgraden vanligen runt 95 procent, vilket gör att Göteborgs-Posten ligger något, men måttligt, under detta genomsnitt. Såväl Dagens Nyheter som Svenska Dagbladet ligger betydligt under ett genomsnitt. Jämför man betalningsgraden i Stockholmsregionen med andra orter där det finns konkurrens mellan två morgontidningar, kan man konstatera att det är Stockholm som skiljer ut sig, inte orter med två tidningar i allmänhet (TSboken, löpande).

Även om de tryckta upplagorna sammantaget alltså är relativt oförändrade över tid i såväl Stockholms- som Göteborgsregionen, kan man konstatera att konkurrensen hårdnat och det har blivit svårare att ta betalt för tidningen. Den hårdnande konkurrensen kan i Stockholm dateras till mitten av 1990-talet. Det var då Metro startade. Konkurrensen ökade ytterligare i början av 2000-talet då Stockholm City startade. Samtidigt kan man anta att andra gratisdistribuerade nyheter, t.ex. via internet, också spelat viss roll för konkurrensen och för betalningsviljan för de abonnerade morgontidningarna. Till detta ska också läggas redan nämnda samhällsförändringar av betydelse för betalningsviljan - när det dessutom finns alternativ som är gratis på flera håll.

Det huvudsakliga skälet till att konsekvenserna av Metros start är relativt små, är att den delvis nådde helt nya grupper av läsare; människor som tidigare inte tagit del av någon morgontidning alls.

\section{Fler läsare}

Upplaga är ett relativt grovt mått, men säger en del om tidningarnas ställning framför allt från ett företagsperspektiv. Men upplaga säger mindre om hur läsningen av tidningar ser ut. Samtidigt som upplagorna går ned i hela Sverige, vilket har flera orsaker (Wadbring \& Weibull, 2005a), är läsningen av framför allt morgontidningar väldigt stabil över tid. Cirka 80 procent av den svenska befolkningen tog 2004 regelbundet del av någon dagstidning, vilket är ungefär samma nivå som i början av 1990-talet och något lägre än i början av 1980talet. $^{8}$

Samtidigt får man inte glömma de regionala skillnaderna inom landet, och det är Stockholmsregionen som skiljer sig från andra delar av Sverige. Under första halvan av 1990-talet - dvs. åren innan Metro startade - låg läsningen av morgontidningar ungefär 10 procentenheter lägre i Stockholmsregionen än i övriga landet (Wadbring 2003). Det fanns således ett hål att fylla på läsarmarknaden i Stockholm jämfört med övriga landet.

Det finns flera sätt att redovisa tidningarnas ställning på läsarmarknaden, och jag har valt tre för att analysera konsekvenserna på läsarmarknaden. För det första räckvidden för enskilda tidningstitlar, för det andra vilket tillskott Metro och City är på tidningsmarknaden och för det tredje vilka grupper Metro och City kommit att fă stor betydelse för. I figur 3 redovisas räckvidden för de enskilda tidningstitlarna, och mönstret är väldigt likt det vi kunde se i figur 1 avseende upplagor: Metro (och efter 2002 även Stockholm City) ser i huvudsak ut att vara ett tillskott och övriga tidningar tappar relativt måttligt i räckvidd. Dagens Nyheter är hårdare drabbad än Svenska Dagbladet, av flera skäl. Ett viktigt skäl är att Svenska Dagbladet har en förhållandevis nischad läsekrets, »up-market«, medan Dagens Nyheter i större utsträckning är »tidningen för alla«. Svenska Dagbladet har också, som vi såg i figur 2, en stor andel tidningsexemplar med stor rabatt och når just därför en något högre räckvidd än vad den annars skulle ha gjort.

I februari 1995 startar Metro, och når under sitt första år ungefär en fjärdedel av stockholmarna. Redan året därpå når man en tredjedel och därefter ligger räckvidden stabilt runt 40 procent, inte så långt under regionens största tidning, Dagens Nyheter, och betydligt över regionens numera fjärdetidning, Svenska Dagbladet. Metro har blivit andratidning, medan Stockholm City blivit tredjetidning, strax efter Metro. 


\section{Figur 3 \\ Morgontidningars räckvidd i Stockholmsregionen, vardagar, 1994-2005 (procent)}

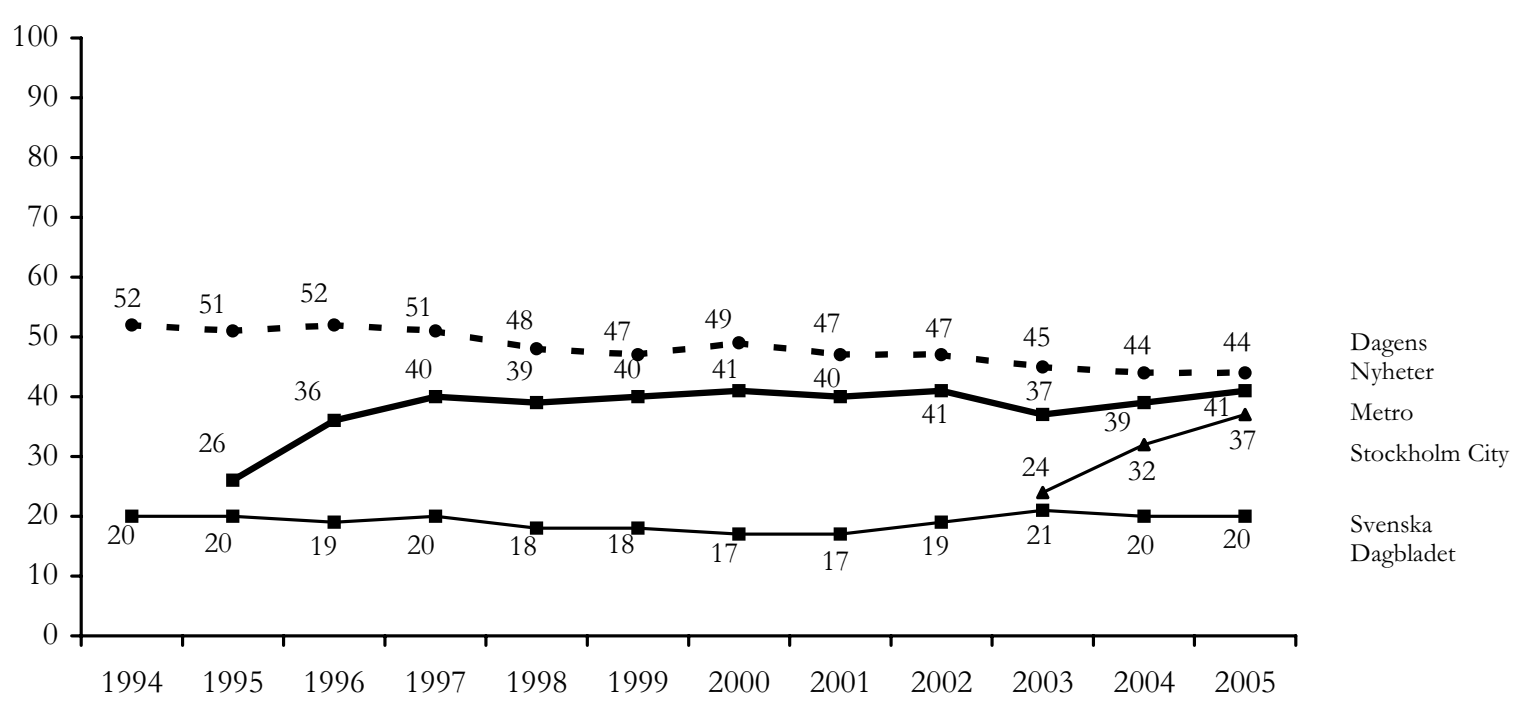

Källa: Orvesto respektive år.

Den nedgång som kan ses över tid för Dagens Nyheter och Svenska Dagbladet är förhållandevis måttlig. Det kan tyda på två saker: att dubbelläsningen av tidningar är mycket stor eller att Metro och Stockholm City nått helt nya läsare samtidigt som de abonnerade tidningarna knappast tappat några av sina läsare. För att få svaret på vilken av de helt disparata förklaringarna som är mest rimlig är det relevant att redovisa ett sammanslaget mått, där de dagliga gratisdistribuerade tidningar inkluderas respektive exkluderas; genom differensen kan de gratisdistribuerade tidningarnas bidrag fastställas. I figur 4 finns en sådan uppställning gjord för samtliga tre storstadsregioner i Sverige.

I Stockholmsregionen är differensen om Metro inkluderas respektive exkluderas ur morgontidningsbegreppet närmare 25 procentenheter, i Göteborgs- respektive Malmöregionerna 10-15 procentenheter. Samtidigt är Metros egen räckvidd ungefär 40 procent i Stockholmsregionen och cirka 35 i Göteborgs- och Malmöregionerna vilket innebär att dubbelläsningen med andra tidningar är relativt stor. ${ }^{9}$ Tar vi Stockholmsregionen som exempel innebär det att ungefär en fjärdedel av befolkningen läser enbart Metro, en knapp femtedel läser Metro och någon annan morgontidning medan nästan hälften läser enbart en eller flera abonnerade morgontidningar och cirka 15 inte läser någon morgontidning alls.

Det är således lätt att konstatera att de dagliga gratisdistribuerade morgontidningarna bidrar till att betydligt fler människor tar del av en morgontidning, gratis eller abonnerad. Det finns studier från andra marknader som visar motsatt resultat: i exempelvis USA har man kunnat påvisa endast ett mycket marginellt tillskott till läsarmarknaden av de dagliga gratisdistribuerade tidningarna (Mahoney \& Collins 2005), men då är också penetrationen av dessa betydligt lägre än i Sverige.

I Sverige däremot kan alltså ett stort tillskott konstateras. Frågan är då för vilka människor dessa tidningar kommit att bli ett tillskott. Det finns många sätt att gruppera människor för att se vilka faktorer som är väsentliga för att förklara beteenden och attityder. Ett sätt som visat sig fruktbart för att fănga flera faktorer på en och samma gång, är att studera boendestrukturer. Flera sociodemografiska fakto- 
Figur 4

Andel av befolkningen i storstadsregionerna som regelbundet läser morgontidning om dagliga gratistidningar inkluderas respektive exkluderas, 2005 (procent)

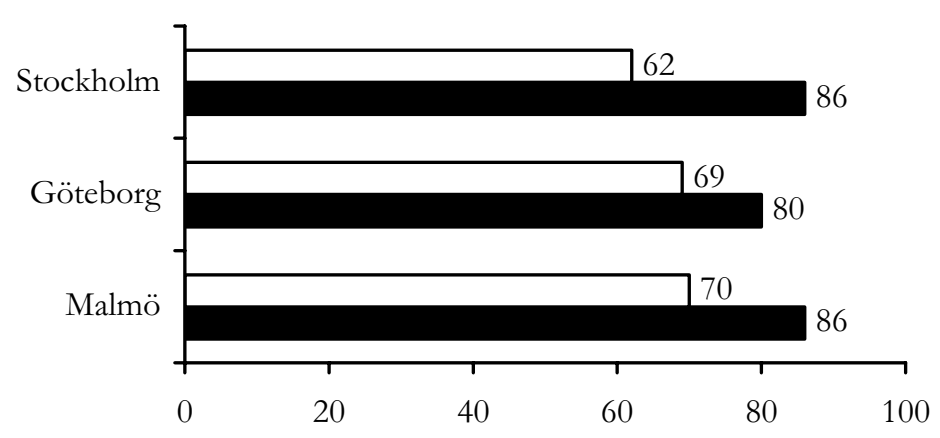

$\square$ Exkl. dagliga gratistidningar

Inkl. dagliga gratistidningar

Källa: Den nationella SOM-undersökningen för Stockholms- och Malmöregionerna, den västsvenska SOM-undersökningen för Göteborgsregionen.

Kommentar: Med regelbunden läsning avses för Stockholms- och Malmöregionen läsning minst 3 dagar/vecka och för Göteborgsregionen 4 dagar/vecka (beroende av olika skalor i formulären). Antalet svarande är i Stockholmsregionen cirka 600 personer, i Göteborgsregion cirka 1800 och i Malmöregionerna cirka 200 personer.

rer tenderar att sammanfalla med geografiska områden, särskilt i storstäder där boendet är relativt segregerat (för en översikt, se Wadbring 2005). Jag har valt att skapa ett index utifrån var människor bor, och använder alltså en surveyundersökning på aggregerad nivå för att skapa grupperingar. Faktorer som ingår i indexet är medelinkomst, andel socialbidragstagare och andel invandrare i olika stadsdelar. Fler, eller andra, socioekonomiska faktorer hade gett samma indelning (ibid.). Bäst dataunderlag för en sådan analys finns i Göteborgs kommun, där Metro funnits sedan 1998. Indexet är relativt i storlek och indelat i fyra kategorier, från resursstarka stadsdelar med hög medelinkomst, låg andel socialbidragstagare och låg andel invandrare till resurssvaga stadsdelar med låg medelinkomst, hög andel socialbidragstagare och hög andel invandrare (tabell 1).

Året innan Metro startade, 1997, är första året som redovisas. Det var då stor skillnad i läsning mellan olika typer av stadsdelar; medan nästan 90 procent av befolkningen i de resursstarka stadsdelarna regelbundet läste en morgontidning var det bara lite drygt hälften av befolkningen i de resurssvaga stadsdelarna som läste en morgontidning. I båda fallen var det i huvudsak Göteborgs-Posten som lästes, trots att det i staden då också fanns en socialdemokratisk daglig morgontidning, låt vara med en mycket liten upplaga. ${ }^{10}$

År 1998 startade Metro, och den fick inte något omedelbart genomslag i de resursstarka områdena - men däremot i de resurssvaga. Första året efter Metros start som redovisas i tabell 1 är 2000, då tidningen funnits i några år och »satt« sig på marknaden. Ungefär 10 procent av befolkningen i de resursstarka stadsdelarna läser då Metro, medan nästan 4 av 10 i de resurssvaga stadsdelarna gör det. I båda fallen ökar sedan Metro något över tid; det gäller också i de båda mellangrupperna av stadsdelar. Ser vi till det tillskott (differensen mellan de båda första raderna i tabellen) som Metro ger tidningsspridningen i de olika stadsdelarna, är det år 2005 knappa 10 procent i de resursstarka medan det är nästan 30 procent i de resurssvaga stadsdelarna.

Mest intressant är emellertid att studera vad som hänt med läsningen av Göteborgs-Posten efter Metro startat. I de resursstarka stadsdelarna står Göteborgs-Posten fortsatt stark, medan en viss 
Tabell 1

Regelbunden läsning av dagliga gratistidningar och prenumererade morgontidningar i olika typer av boendeområden, Göteborgs kommun, 1997-2005 (procent)

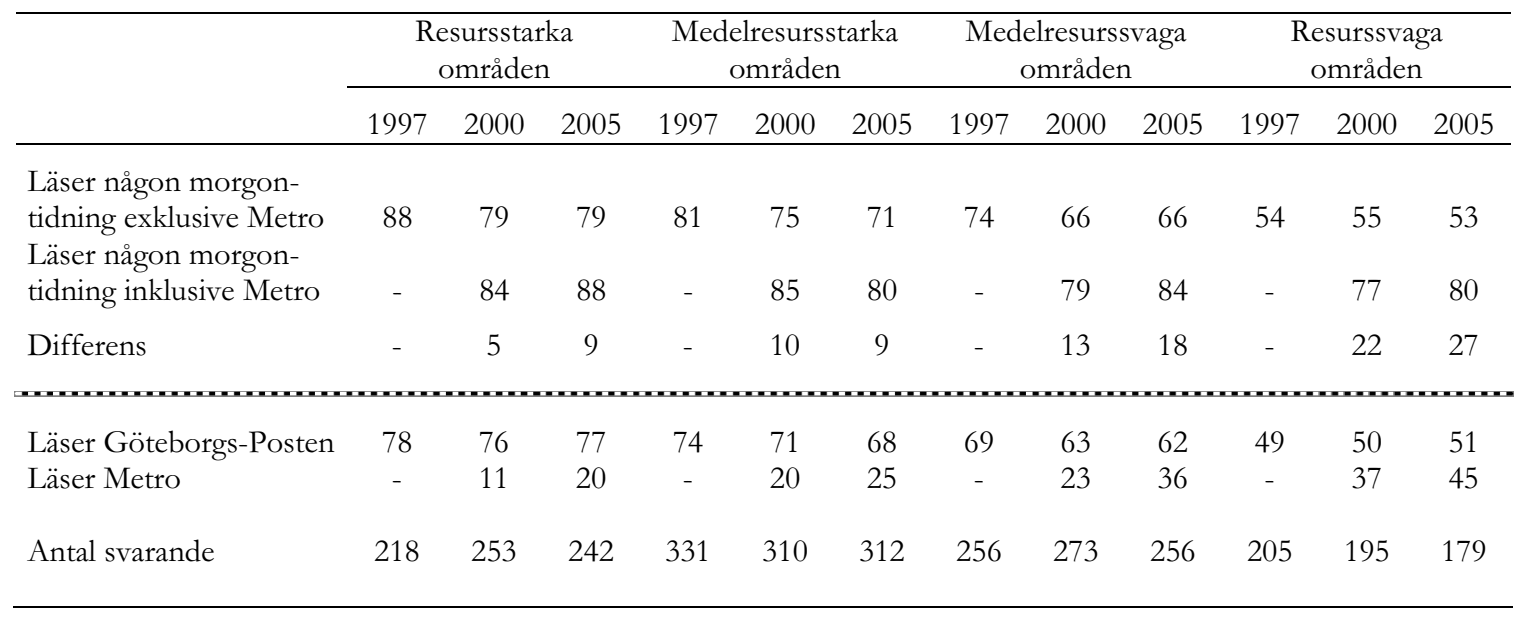

Källa: Den västsvenska SOM-undersökningen respektive år.

Kommentar: Med regelbunden läsning avses läsning minst 4 dagar/vecka. Indexet, som är relativt, bygger på Göteborgs 21 stadsdelsnämnder som rangordnats efter medelinkomst, andel familjer med socialbidrag och andel invandrare.

nedgång kan ses i de båda mellanstarka grupperingarna. I de resurssvaga områdena är läsningen av Göteborgs-Posten stabil. Det tyder på att »botten var nådd « för Göteborgs-Posten i de resurssvaga stadsdelarna redan innan Metro kom, men i de mellanliggande stadsdelarna har en större andel av invånarna valt att byta tidning.

Sammantaget har marknaden totalt sett vidgats. Betydligt fler läser en tidning idag än innan fenomenet dagliga gratistidningar fanns. Men om resurssvaga grupper är en grupp som traditionella dagstidningar länge haft svårt att nå, är unga människor en annan. Det gäller i Sverige likväl som internationellt. Det har spekulerats kring om unga beter sig som de gör för att de är just unga, eller om det beror på att de tillhör en annan slags generation (se Khattak 2006; Nilsson 2005). De ungas förändrade konsumtion av papperstidningar sammanfaller $\mathrm{i}$ viss mån med ett förändrat svenskt medielandskap, där dagliga gratistidningar är ett fenomen, internet ett annat, kommersiell tv ett tredje. Kommer de någonsin att landa i morgontidningsvärlden på samma sätt som generationerna före dem? Jag har två svar på den frågan. Svaret är nej, om man med morgontidningar endast räknar abonnerade sådana. Men svaret är istället ja om vi också kan inkludera de tidningar som är gratisdistribuerade. Ur ett marknadsperspektiv är svaret således negativt, men ur ett samhällsperspektiv positivt, se figur 5 .

Figur 5 är uppdelad i tre geografiska regioner där Metro finns; Stockholm, Göteborg och de städer där den nationella editionen av tidningen utkommer (se Wadbring 2006). Inom varje region finns en åldersuppdelning, och för varje åldersgrupp tre staplar. Den första visar hur läsningen av morgontidningar ser ut om dagliga gratistidningar exkluderas (grå), den andra visar läsningen om de inkluderas (svart) och den tredje - och kanske allra mest intressanta - visar hur läsningen såg ut i respektive åldersgrupp och region året innan Metro startade i respektive region (vit) vilket alltså är 1994 i Stockholm, 1997 i Göteborg och 2003 i övriga landet där den finns.

De mönster som kan ses gäller alla regioner, men är allra tydligast i Stockholm. Ungefär 65 procent av de unga läste en morgontidning i Stockholmsre- 
Figur 5

Andel av befolkningen i olika regioner som regelbundet läser morgontidning om dagliga gratistidningar inkluderas respektive exkluderas, efter ålder, 2005 (procent)

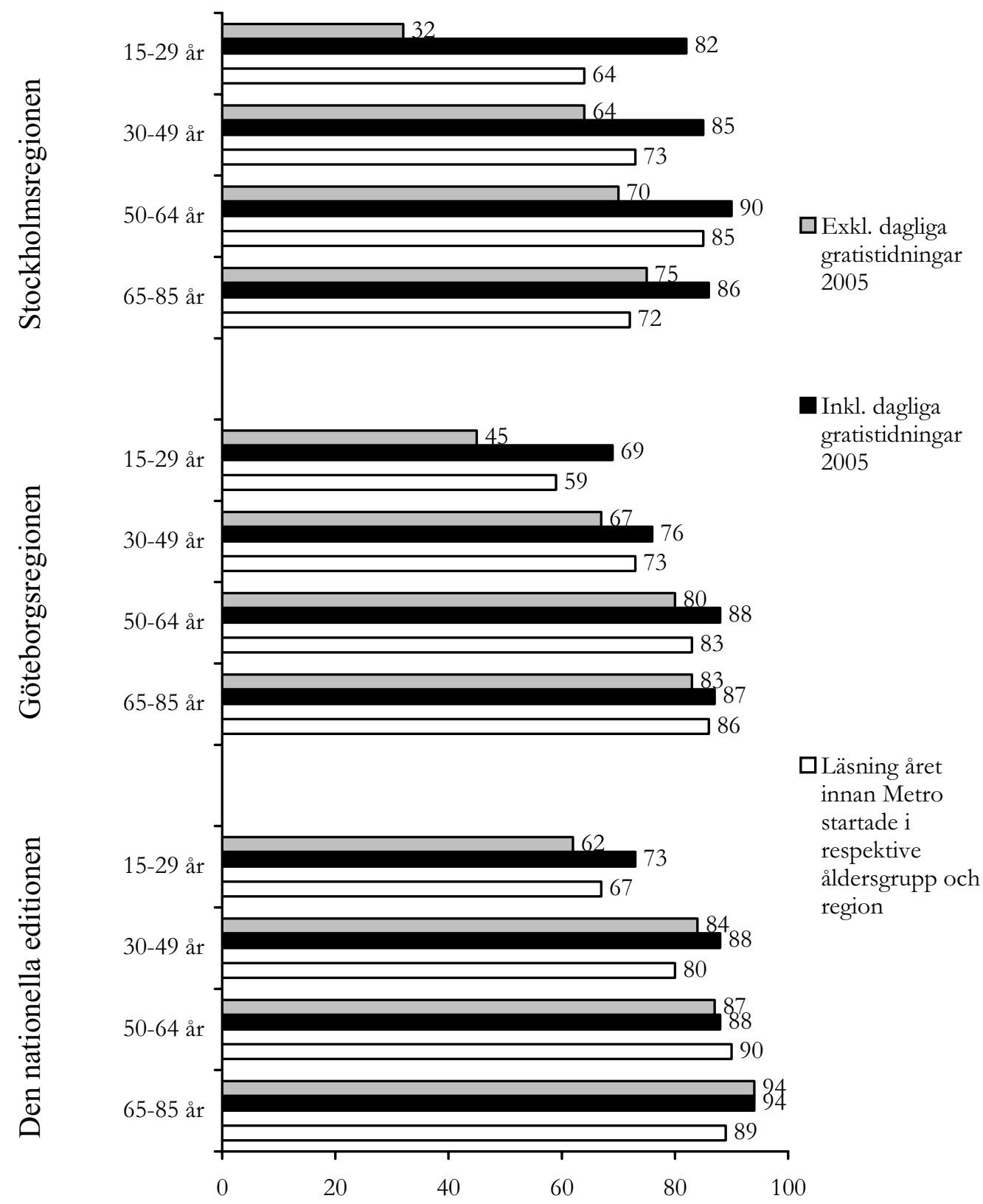

Källa: Den nationella SOM-undersökningen för Stockholmsregionen och den nationella editionen, den västsvenska SOM-undersökningen för Göteborgsregionen.

Kommentar: Med regelbunden läsning avses för Stockholmsregionen och den nationella editionen läsning minst 3 dagar/vecka och för Göteborgsregionen 4 dagar/vecka (beroende av olika skalor i formulären). Antalet svarande är i Stockholmsregionen cirka 600 personer (dock endast 300 personer år 1994, vit stapel), i Göteborgsregion cirka 1800 och avseende den nationella editionen cirka 700 personer. 
gionen året innan Metro startade. Idag är det över 80 procent. Men om Metro och City exkluderas, är det bara dryga 30 procent av de unga som kan karaktäriseras som morgontidningsläsare. Det är en anmärkningsvärd differens på 50 procentenheter. Precis samma mönster kan ses i de andra regionerna, om än inte lika tydligt, och framför allt i de yngre åldersgrupperna. Medelålders uppvisar samma mönster, men skillnaderna är inte tillnärmelsevis så stora som bland de unga. Bland äldre personer - här alla över 50 år - utanför Stockholmsområdet spelar Metro ingen större roll. Dubbelläsningen har ökat, men man har inte bytt tidning utan bara lagt till ytterligare en i sin konsumtion.

Unga människor - liksom resurssvaga grupper - är alltså inte på något sätt negativa till papperstidningar som fenomen. Men en del av dem kan och/eller vill inte betala för dem. Ånyo måste dock påminnas om att det inte bara kan vara Metro som spelat roll för ett förändrat konsumtionsmönster bland unga - problemet att nå unga och resurssvaga grupper har funnits längre än Metro funnits. Den rimliga tolkningen är emellertid att Metro och liknande tidningar ändå påskyndat processen att det inte är självklart att abonnera på en morgontidning som tidigare; det är enklare att låta bli det om det finns ett tillräckligt gott gratisalternativ. Där är Metro ett av gratisalternativen, medan kanske framför allt internet är ett annat. Antagligen är en rimlig tolkning också att unga vuxna i Stockholm inte kommer återvända till den abonnerade pressen i någon större utsträckning då de blir äldre. Det bör även noteras att i Stockholmsregionen har tidningsläsning bland unga ökat med nästan 20 procentenheter om dagliga gratistidningar räknas in.

Sett ur ett marknadsperspektiv kan hävdas att enskilda tidningstitlar tappat tillräckligt mycket för att det ska vara ett problem, men sett ur ett samhällsperspektiv där de enskilda titlarna blir mindre viktiga än den totala läsningen, så måste utvecklingen ses i mer positiva termer.

\section{Mer annonser}

Utan läsare, inga reklamintäkter. Utan reklamintäkter, ingen verksamhet. Det är ett faktum som gäller såväl betalda som gratisutgivna tidningar.
Det är tillgången till läsare som annonsörerna betalar för. Frågan är då om ytterligare tidningar på marknaden som når en delvis ny publik - om än inte primärt den mest köpstarka publiken - haft någon betydelse för redan etablerade tidningar? Ingen abonnerad morgontidning skulle kunna kompensera uteblivna annonsintäkter med ökade läsarintäkter i särskilt stor utsträckning utan att samtidigt tappa läsare, så att behålla befintliga annonsintäkter är viktigt. Därför var en - och sedan ytterligare en i Stockholm - ny annonsfinansierad aktör på arenan knappast särskilt välkommen.

Annonsmarknaden är mycket konjunkturberoende. Under 1990-talet ökade reklammarknaden som helhet; vi kan tala om en högkonjunktur med låg inflation. Storstadsmorgontidningarna i allmänhet ökade sina reklamintäkter räknat i kronor, men inte i andel av reklamkakan. Förklaringen är att tidningarna höjde priserna kraftigt - därför ökade annonsintäkterna i kronor - samtidigt som konkurrensen om reklamen totalt sett hårdnade eftersom nya medier - radio, tv och internet - tillkom på reklammarknaden. Reklamfinansierad radio och tv fanns i princip inte i Sverige förrän på 1990-talet (Gustafsson 2000, Trotzig 2004, Wadbring 2003). Allt detta sammantaget, plus att det är svårt att ta fram valida data på annonsintäkter, innebär att det är svårt att isolera Metros betydelse för eventuella förändringar på annonsmarknaden. Men vi ska ändå göra ett försök. De data som annonsintäkterna bygger på, kommer från respektive tidnings årsredovisning. Det är endast ett sammantaget mått som inte säger något alls om olika typer av annonsintäkter, men det är det bästa mått som kan åstadkommas när man befinner sig utanför de enskilda tidningarna.

I figur 6 redovisas annonsintäkterna för Dagens Nyheter och Svenska Dagbladet respektive Göteborgs-Posten samt hur BNP förändrats över tid i Sverige. ${ }^{11}$ Alla uppgifter är omräknade till fasta priser i 2001 års penningvärde för att lättare kunna jämföras. Procentuella ökningar och minskningar är också inlagt.

De första redovisade åren på 1990-talet visar en viss uppgång för såväl Dagens Nyheter som Svenska Dagbladet vad gäller annonsintäkter. Efter att Metro startade 1995 kan en viss stagnation ses för båda de abonnerade tidningarna i 


\section{Figur 6 \\ Annonsintäkter för Dagens Nyheter, Svenska Dagbladet och Göteborgs-Posten 1993-2004 (netto, fasta priser i 2001 års värde, tusentals kronor)}

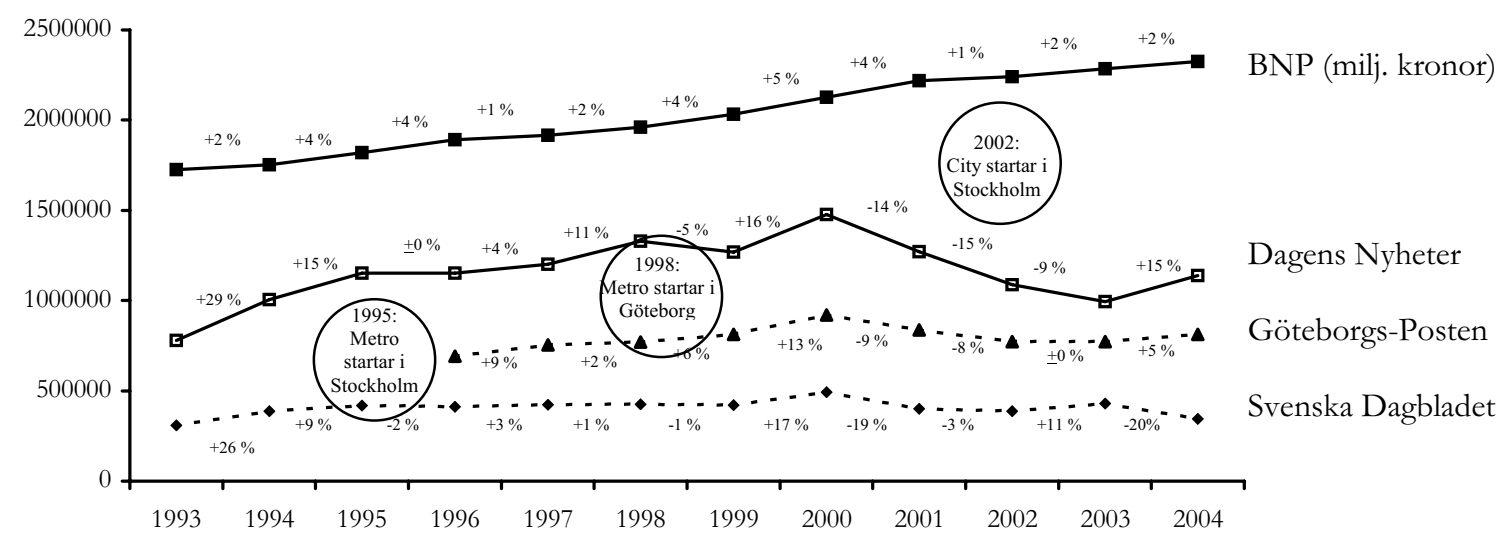

Källa: Respektive tidnings årsredovisning (bearbetning).

Kommentar: I GPs årsredovisningar finns inte annonsintäkter specificerade förrän 1997 (då även 1996 redovisas). Sedan 2002 särredovisas inte annonsintäkter i Dagens Nyheters årsredovisning; uppgifterna från Dagens Nyheter 2002-2004 är muntliga från tidningens medarbetare.

Stockholm. Svenska Dagbladet ligger sedan på ungefär samma nivå under hela andra halvan av 1990-talet, medan Dagens Nyheter ökar något. Ökningen i annonsintäkter kan antagligen primärt tillskrivas kraftigt höjda priser, och möjligen kan även stabiliteten för Svenska Dagbladet ha samma förklaring; högre pris för färre annonser (jfr. Gustafsson 2000).

År 2002, samma år som Stockholm City startar, slutade Dagens Nyheter att redovisa sina annonsintäkter i årsredovisningen av konkurrensskäl, medan Svenska Dagbladet fortsatte att göra det (de uppgifter som finns för Dagens Nyheter 2002-2004 är därför muntliga från tidningens medarbetare). Annonsintäkterna ökar för Svenska Dagbladet mellan 2002 och 2003, men en kraftig nedgång kan ses 2004. För Dagens Nyheter är mönstret nästan motsatt med en uppgång 2004 efter flera års stor nedgång. En rimlig förklaring till detta kan i viss mån tillskrivas Metro som i början av 2004 startade en bostadsbilaga till tidningen som tog en mycket stor del av alla bostadsannonser. Svenska Dagbladet förlorade i princip all bostadsannonsering medan Dagens Nyheter tog upp konkurrensen och också valde att satsa på bostadsmarknaden.

I Göteborgsregionen där Metro startade 1998 kan ingen omedelbar nedgång ses för Göteborgs-Posten. Efter år 2000 finns dock en nedgång i redovisade annonsintäkter. Frågan är om denna nedgång kan tillskrivas Metro? Det kan inte uteslutas, men heller inte verifieras.

Sammantaget är det inte självklart på vilket sätt någon av de dagliga gratisdistribuerade tidningarna har något med annonsintäkternas nedgångar för den abonnerade pressen att göra. Att Metros enorma satsning på bostadsannonseringen haft effekt torde dock vara otvetydigt, och även i övrigt kan man anta att de dagliga gratistidningarna haft viss betydelse för annonsmarknaden. Men det behövs ett mer detaljerat underlag än årsredovisningar från de abonnerade tidningarna för att kunna se vilka specifika annonsmarknader som verkar ha förändrat sig. Här hade det också varit mycket spännande att se om starten av Stockholm City 
hade någon effekt på Metro på annonsmarknaden - men eftersom Metro International inte särredovisar de enskilda titlarna i årsredovisningarna är det inte möjligt att analysera.

Hur annonsmarknaden hade sett ut om Metro inte hade funnits, vet vi heller inte. Vad vi däremot vet, är att många flera reklamfinansierade medier - såväl lokala som nationella - också såg dagens ljus under 1990-talet, vilket gör det än svårare att isolera en enskild ny tidnings betydelse för befintliga tidningar.

\section{Konklusion}

Vad kan då sammantaget sägas om konsekvenserna på tidningsmarknaden av Metros och även Stockholm Citys start? Man kan och bör diskutera det på flera olika sätt. Negativa ekonomiska konsekvenser på marknaden för den abonnerade pressen finns, men ska inte överdrivas. Vissa nedgångar startade långt innan dagliga gratisdistribuerade tidningar fanns, och vi vet inte hur det hade sett ut om denna typ av tidning inte startats. Det gäller såväl upplage- som annonsmarknaden. Den ekonomiska konsekvens som är rimligast att knyta till starten av Metro och även Stockholm City i ett senare skede, är faktumet att de abonnerade tidningarna har fătt svårare att ta betalt för sin upplaga. Särskilt gäller det Svenska Dagbladet i som idag är fjärdetidning på stockholmsmarknaden. Från ett marknadsperspektiv kan vi genom rimliga bedömningar anta att de dagliga gratisdistribuerade tidningarna haft en viss, men måttlig, negativ betydelse för de abonnerade tidningarna.

Om de ekonomiska konsekvenserna av Metros och Stockholm Citys start på övriga tidningar kan sägas finnas men vara relativt måttliga, är det lättare att slå fast de dagliga gratisdistribuerade tidningarnas roll på läsarmarknaden, dvs. om vi istället anlägger ett samhällsperspektiv. På läsarmarknaden kan konstateras mer positiva konsekvenser: ett ökat allmänt läsande, särskilt bland grupper som tidigare inte läst någon dagstidning, särskilt resurssvaga grupper. Även bland unga kan ett ökat tidningsläsande ses - men inte av abonnerade tidningar. Särskilt i Stockholm är detta tydligt. Här handlar det inte huvudsakligen om en vidgad marknad, utan om att unga övergivit abonnerade tidningar till förmån för gratisdistribuerade. Läsningen totalt sett har dock också ökat bland de unga, så även här kan man i viss mån tala om en vidgad marknad.

Som nämndes redan inledningsvis bygger en slutsats som denna på att innehållet i de gratisdistribuerade morgontidningarna på något sätt kan likställas med de abonnerade morgontidningarnas. Man kan naturligtvis diskutera om äpplen och päron kan jämföras på detta sätt, men jag menar att likväl som storstadsmorgontidningarna kan jämföras med lokala morgontidningar - vilket alltid görs - så kan abonnerade och gratisdistribuerade storstadstidningar jämföras med varandra. Liksom äpplen och päron båda är frukter, är de båda tidningstyperna tidningar även om de smakar lite olikartat och räcker olika länge.

Metro som titel betraktad har sådana synergifördelar genom att verka världen över, att den av det skälet blir en mycket stark aktör. Och Metro som fenomen har fått många efterföljare, vilket gör det svårt att se något enda skäl till att expansionen av dagliga gratisdistribuerade tidningar inte skulle fortsätta. Sammantaget leder detta till att man kan konstatera att fenomenet dagliga gratistidningar är här för att stanna och Metro är den starkaste titeln av dem alla med en marknadsandel på ungefär en tredjedel av världens dagliga gratistidningar (Bakker \& Wadbring 2005). Beroende på hur tidningsmarknaden ser ut där en Metro - eller en annan daglig gratisdistribuerad tidning - startar kan vi förvänta oss olika effekter. Den svenska traditionella tidningsmarknaden är stark, och den påverkan en daglig gratisdistribuerad tidning kan ha är måttlig. På en marknad med svag press borde effekten vara likartad; det finns inte mycket för den befintliga pressen att förlora och därmed borde en ny gratisdistribuerad tidning kunna i huvudsak vara ett tillskott, på såväl läsars- som annonsmarknaden. Vad som kan komma att hända på de marknader där pressen är medelstark är betydligt svårare att förutse utifrån de svenska erfarenheterna (se Hallin \& Mancini 2004 för en länderöversikt). En grundförutsättning för att en daglig gratisdistribuerad tidning ska ha någon betydelse är emellertid att den har en hög penetration, och i dagsläget har tidningarna det på vissa håll, men inte på andra. Det är skillnad att ge ut en tidning $i$ Stockholm eller Göteborg jämfört med New York eller Hong Kong. 


\section{Framtiden: mot ett nytt firebladssystem?}

En världsvid expansion av dagliga gratistidningar parallellt med en ytterligare expansion av framför allt internet reser nya frågor: kommer medier som uppfattas som gratismedier att ta över helt, framför allt hos den nya generationen? Svaret är enligt min mening: nej - men de kommer att ta en allt större marknadsandel. Det kommer emellertid alltid att finnas utrymme för betalda medier; om historien lärt oss något, så är det just det. Bara för att nya medier dyker upp på marknaden, försvinner inte de gamla. De kan möjligen få en förändrad funktion, en förändrad marknadsandel eller en förändrad spridning - men försvinner gör de inte. Vad gäller traditionell tryckt press, är det rimligt att tänka sig en tydligare uppdelning av marknaden än vad vi ser idag - och de digitala nyhetssajterna bör också tas med i en sådan analys; fortfarande hör dessa i huvudsak till just tidningsföretagen (Bergström 2004). I figur 7 har jag skissat hur det skulle kunna se om till exempel tio år (jfr Wadbring \& Weibull 2005a); ett nytt slags firebladssystem som utgår från det historiska danska systemet med fyra tidningar med olika politisk färg i varje stad av rang (Gustafsson 1996) - men om det vid tidpunkten för förra sekelskiftet handlade om politisk differentiering, handlar det vid detta sekelskifte snarare om ekonomisk.

I firebladssystemet finns två skiljelinjer, en handlar om kostnad och en annan om målgrupp. Fortfarande tänks de lokala morgontidningarna vara basen i tidningssystemet, men i motsatt ruta finns de dagliga gratistidningarna där de läsare återfinns som valt bort den traditionella morgontidningen. Kvällstidningar och digitala/specialiserade tidningar har inte berörts så mycket i denna artikel, men det finns en högstatusgrupp som läser digitala tidningar i stor utsträckning och som signifikant minskat sin morgontidningsläsning (Bergström 2004) och kvällspressen börjar alltmer närma sig populärpressen och tappar i förtroende bland befolkningen (Wadbring \& Weibull 2005b). Karl Erik Gustafsson, professor emeritus i massmedieekonomi, skrev (1996:17) om firebladssystemet från förra sekelskiftet att genom partiernas och folkrörelsernas tidningar blev vanan att läsa tidning spridd till alla skikt av samhället. Idag står inte partier och folkrörelser bakom tidningarna utan det gör enskilda företag med vinstintressen - men konsekvensen av att det finns olika slags tidningar är nu som då att alla skikt i samhället finner åtminstone en tidning att läsa.

\section{Figur 7}

En skiss för dagstidningsföretags kärnprodukter i mitten av 2010-talet; mot ett nytt firebladssystem?

\section{$\underline{\text { Kostnad }}$}

\begin{tabular}{|c|c|c|}
\hline & Abonnemang/lösnummer & Gratis \\
\hline $\begin{array}{r}\text { Högstatus/ } \\
\text { "up market" }\end{array}$ & $\begin{array}{l}\text { Traditionella lokala } \\
\text { morgontidningar }\end{array}$ & $\begin{array}{c}\text { Specialiserade tidningar/ } \\
\text { digitala tidningar }\end{array}$ \\
\hline $\begin{array}{r}\text { Lågstatus/ } \\
\text { "down market" }\end{array}$ & $\begin{array}{l}\text { Kvällstidningar } \\
\text { på papper }\end{array}$ & $\begin{array}{l}\text { Dagliga } \\
\text { gratistidningar }\end{array}$ \\
\hline
\end{tabular}




\section{Referenser}

Bakker, P. (2002a). Free Daily Newspapers - Business Models and Strategies. In The International fournal on Media Management, vol 4, no 3 (180-187).

Bakker, P. (2002b). Reinventing Newspapers. Free Dailies - Readers and Markets. Updated and revised version of a paper presented at the $5^{\text {th }}$ World Media Economic Conference, Turkku Finland, 9-11 May 2002.

Bakker, P. \& Wadbring, I. (2005). Free Dailies - a Success the Machiavellian Way? Paper from the Conference: Challenges at the Top: Leadership in Media Organizations. The Media Management and Transformation Centre in Jönköping, Sweden, 30 September - 1 October 2005.

Baldasty, G. J. (1992). The Commercialization of News in the Nineteenth Century. Madison and London: The University of Wisconsin Press.

Bergström, A. (2004). nyhetsvanor.nu Nyhetsanvändning på internet 1998 till 2003. Göteborg: Institutionen för journalistik och masskommunikation, Göteborgs universitet.

Dagens Nyheters årsredovisningar (löpande).

Dansk Presse (löpande).

Gustafsson, K.E. (1996). Dagspressen i Norden. Struktur och ekonomi. Lund: Studentlitteratur.

Gustafsson, K.E. (2000). Dagspressen och reklamkonjunkturen. Göteborg: Handelshögskolan.

Göteborgs-Postens årsredovisningar (löpande).

Hallin, D.C. \& Mancini, P. (2004). Comparing Media Systems. Three Models of Media and Politics. Cambridge: Cambridge University Press.

Hultén, L. J. (1999). Orden och pengarna. Om kamp och kapitulation inom journalistiken. Stockholm: Natur och kultur.

Høst, S (1996). Aviskonkurransen. Nye og gamle teorier belyst gjennom A-pressens utvikling. Fredrikstad: Institutt for journalistikk.

Høst, S. (2000). Journalistikk i gratisaviser. En sammenlignende analyse. Fredrikstad: Institutt for journalistikk.

Ifra (2005). Free Newspapers - an Update. Darmstadt: Ifra Special Report 6.25.2.

Khattak, J. (2006). Free and „Liter Newespapers: The Answer For the New Generation? Dallas: INMA.

Mahoney, K.P. \& Collins, J.H. (2005). Consumer Newspaper Choise in Markets With Free Print Options: Are Free Daily Newspapers Competition or Opportunity for Traditional Paid Products.? Paper presented at the Conference: Worldwide Readership Research Symposium 2005 in Prague.

McAllister, M. (1996). The Commercialization of American Culture. New Advertising, Control and Democracy. Thousand Oaks, London and New Delhi: Sage Publications.

McManus, J.H. (1994). Market Driven Fournalism. Let the Citizen Beware? Thousand Oaks, London and New Delhi: Sage.

McQuail, D. (2005). McQuail's Mass Communication Theory. $5^{\text {th }}$ Edition. London: Sage Publications.

Nilsson, Å. (2005). Tidningsläsandets åldrar och generationer. I Bergström, A.; Wadbring, I. \& Weibull, L. (red). Nypressat. Ett kvartssekel med svenska dagstidningsläsare. Göteborg: Institutionen för journalistik och masskommunikation, Göteborgs universitet.

Nord, L. \& Strömbäck, J. (red) (2004). Medierna och demokratin. Lund: Studentlitteratur.
Orvesto (löpande). Stockholm: Research International.

Picard, R.G. (1993). Economics of Daily Newspaper Industry. In Alexander, A.; Owers, J. \& Carvet, R. (Eds.). Media Economy. Theory and Practice. Hillsdale, Hove and London: Lawrence Erlbaum.

Picard, R.G. (2001). Strategic Responses to Free Distribution Daily Newspapers. In The International fournal of Media Management, vol 2, no 3 (167-172).

Price, C.L. (2002). Threats and Opportunities of Free Newspapers. Dallas and Antwerpen: INMA.

SOM-undersökningarna (löpande). Göteborg: SOM-institutet, Göteborgs universitet.

SOU 2006:8 (2006). Mångfald och räckvidd. Slutbetänkande av Presskommittén 2004. Stockholm: Fritzes.

Sternvik, J.; Weibull, L. \& Nilsson, A. (2005). Dagstidningsläsningens teori och empiri. I Bergström, A.; Wadbring, I. \& Weibull, L. (red). Nypressat. Ett kvartssekel med svenska dagstidningsläsare. Göteborg: Institutionen för journalistik och masskommunikation, Göteborgs universitet.

Svenska Dagbladets årsredovisningar (löpande).

Tidningsutgivarna (2005). Svensk dagspress 2005. Stockholm: Tidningsutgivarna (broschyr).

Trotzig, E. (2004). Reklam. I Carlsson, U. \& Facht, U (red). Mediesverige 2004. Statistik och analys. Göteborg: Nordicom-Sverige, Göteborgs universitet.

TS-boken (löpande). Stockholm: Tidningsstatisk AB.

Wadbring, I. (2003). En tidning i tiden? Metro och den svenska dagstidningsmarknaden. Göteborg: Institutionen för journalistik och masskommunikation, Göteborgs universitet.

Wadbring, I. (2005). Strukturer och kulturer. I Bergström, A.; Wadbring, I. \& Weibull, L. (red). Nypressat. Ett kvartssekel med svenska dagstidningsläsare. Göteborg: Institutionen för journalistik och masskommunikation, Göteborgs universitet.

Wadbring, I. (2006). Metro Goes National. I Holmberg, S. \& Weibull, L (red). Du stora nya värld. Trettiofyra kapitel om politik, medier och samhälle. Göteborg: SOM-institutet, Göteborgs universitet.

Wadbring, I. \& Weibull, L. (1996). Räckvidd och läsvana 1986-1995. En nivåjämförelse mellan två olika tidningsmått. I Carlsson, U. (red). Rapport från 1996 års Mediebarometerseminarium. Göteborg: Nordicom-Sverige, Göteborgs universitet.

Wadbring, I. \& Weibull, L. (2005a). Dagstidningen i ett femtioårsperspektiv. I Bergström, A.; Wadbring, I. \& Weibull, L. (red). Nypressat. Ett kvartssekel med svenska dagstidningsläsare. Göteborg: Institutionen för journalistik och masskommunikation, Göteborgs universitet.

Wadbring, I. \& Weibull, L. (2005b). Medieförtroende - en framgångsfaktor? I Holmberg, S. \& Weibull, L. (red) Lyckan kommer, lyckan går. Göteborg: SOM-institutet, Göteborgs universitet.

WAN (2005). World Press Trends 2004. Paris: World Association of Newspapers.

www.metro.lu (2006).

www.ts.se $(2006)$. 
Ingela Wadbring er fil.dr. og medieforsker ved Institut for Journalistik og Massekommunikation på Göteborg Universitet.

\section{Noter}

1 Med Sverige avser jag här huvudsakligen Stockholmoch Göteborgsmarknaden. Metro har också en edition i Malmö, men startade där bara något år innan den socialdemokratiska tidningen Arbetet lades ned, och de eventuella konsekvenser man kan se på Malmömarknaden går därför inte att isolera till Metros start (se Wadbring 2003 för vidare diskussion). Metros svenska riksupplaga startade 2004 och finns analyserad i Wadbring (2006).

2 Det har funnits fler dagliga gratistidningar på Stockholmsmarknaden, men dessa har inte överlevt särskilt länge (se Wadbring 2003).

3 Även presstöd är en viktig inkomstkälla för vissa tidningar. Den största stödformen i Sverige är det direkta presstödet som enskilda andratidningar kan få. Svenska Dagbladet i Stockholm är en av de största mottagarna av direkt presstöd. Indirekta stöd och distributionsstöd gäller däremot alla abonnerade tidningar. Gratisdistribuerade tidningar kan emellertid inte få något slags presstöd.

4 Den politiska synen på tidningarnas viktiga samhällsroll kan utläsas genom just införandet av presstödet på 1970-talet. I den senaste pressutredningen (SOU 2006: 8) föreslås inga radikala förändringar då man menar att fördelarna överväger nackdelarna vad gäller stödåtgärder.
5 En synonym till kvällstidningar är tabloider, vilket är ett lika missvisande begrepp som kvällstidningar eftersom i princip samtliga tidningar i Sverige har tabloidformat. Jag har därför valt att använda det allmänt vedertagna begreppet kvällstidningar trots att utgivningstidpunkten är morgonen.

6 Abonnerade och gratisdistribuerade tidningar mäts inte på samma sätt; de abonnerade tidningarna kan revideras på ett annat sätt än de gratisdistribuerade och ger därmed ett säkrare mått (se www.ts.se för en översikt). Under år 2000 fanns två ytterligare dagliga gratistidningar på marknaden, Stockholm News och Everyday, men dessa fanns under fyra respektive sex månader innan de lades ned, varför de inte finns med i redovisningen.

7 Kvällstidningarna utesluts härefter i redovisningen då det inte i någon analys finns något som tyder på att de konkurrerar på samma marknad som de dagliga gratisdistribuerade tidningarna.

8 Det gäller oavsett om man använder ett frequency- eller ett recencymått (se Sternvik, Weibull \& Nilsson, 2005).

9 Orvesto som mäter räckvidd är inte helt jämförbar med SOM-undersökningarna som mäter regelbunden användning; nivåerna är dock likartade då räckvidd jämförs med regelbunden läsning 4-5 dagar/vecka (Wadbring \& Weibull, 1996). Stockholms- och Malmöregionen som här (av skaltekniska skäl) redovisas med regelbunden läsning minst 3 dagar/vecka är därför inte helt rättvisande jämfört med räckvidd.

10 Socialdemokratiska Arbetet lades ned år 2000 och nådde under sin levnad inte mer än ungefär 5 procent av befolkningen i Göteborgsregionen.

11 Jämfört med tidigare redovisningar som handlar om upplagor och läsning i respektive region, gäller figur 5 respektive tidnings totala intäkter. 